УДК 325.54(477.6)

\title{
ОБЛІК ТА РЕГУЛЮВАННЯ ПРОЦЕСІВ МІГРАЦІї НАСЕЛЕННЯ НА СХОДІ УКРАЇНИ
}

\section{ACCOUNTING AND REGULATION OF MIGRATION PROCESSES IN EASTERN UKRAINE}

\author{
Подлужна Наталія Олександрівна \\ доктор економічних наук, доцент, \\ ДВНЗ «Донецький національний технічний університет» \\ ORCID: https://orcid.org/0000-0003-4366-4969 \\ Лизунова Олена Миколаївна \\ доктор економічних наук, профресор, \\ ДВНЗ «Донецький національний технічний університет» \\ ORCID: https://orcid.org/0000-0002-0083-4422 \\ Тарасенко Денис Леонідович \\ доктор економічних наук, професор, \\ Донецький державний університет управління, Маріуполь \\ ORCID: https://orcid.org/0000-0002-6250-3442 \\ Podluzhna Nataliia, Lyzunova Olena \\ SEIU «Donetsk National Technical University» \\ Tarasenko Denys \\ Donetsk State University of Management, Mariupol
}

\begin{abstract}
На соціально-економічний розвиток країни, її територіальну цілісність і національну безпеку великий вплив мають міграційні процеси. Проблема міграції населення є актуальною для України в умовах загострення демограсрічних і соціально-економічних проблем. Стаття присвячена аналізу міграційних процесів населення та їх впливу на економіку країни. Проаналізовано зміст основних механізмів регулювання міграційних потоків. Представлено аналіз динаміки і сучасного стану процесу міграції населення, на основі якого запропоновано напрями вдосконалення системи регулювання міграції населення. Розглянуто причини виникнення позитивних і негативних наслідків міграції населення. Досліджено думки фрахівців з цієї проблеми. Стаття містить прогнози тенденцій міграційних процесів. Проведено аналіз міграційних процесів в Україні. Представлено результати аналізу динаміки і сучасного стану міграційних процесів. Оцінено вплив внутрішньої міграції на економіку країни. На основі представленого аналізу запропоновано напрями удосконалення системи регулювання внутрішньої міграції. Розширено уявлення про основні принципи та напрямки державної міграційної політики, яких має дотримуватися уряд України під час її фрормування. В статті проаналізована кількість переміщених осіб, які потребують допомоги за період 2016-2020 рр. на прикладі Управління соціального захисту населення Ясинуватської райдержадміністрації. Проведено дослідження динаміки виплати щомісячної адресної допомоги в розрізі контингенту отримувачів на території Донецької області Ясинуватського району, які переміщуються з тимчасово окупованої території та районів проведення антитерористичної операції за період 2016-2020 рр. Досліджено тенденції динаміки основних показників виконання бюджетної програми 2501480 «Надання щомісячної адресної допомоги внутрішньо переміщеним особам для покриття витрат на проживання, в тому числі на оплату житлово-комунальних послуг». Результати цього дослідження можуть стати основою для фрормування міграційної політики України за європейськими стандартами. Визнання та престиж Україні у світі залежать від чіткості та обґрунтованості міграційної політики, від подальшого розвитку і ефрективності міграційних процесів.
\end{abstract}

Ключові слова: міграційні процеси, робоча сила, внутрішньо переміщені громадяни, бюджетні програми, тимчасове розміщення, дискримінація, соціальний захист населення.

На социально-экономическое развитие страны, ее территориальную целостность и национальную безопасность большое влияние имеют миграционные процессы. Проблема миграции населения является ак- 
туальной для Украины. Статья посвящена анализу миграционных процессов населения и их влияния на экономику страны. Проанализировано содержание основных механизмов регулирования миграционных потоков. Представлен анализ динамики и современного состояния процесса миграции населения. На основе представленного анализа предложены направления совершенствования системы регулирования миграции населения. Рассмотрены причины возникновения положительные и отрицательные последствия миграции населения. Исследованы мнения специалистов по этой проблеме. Статья содержит прогнозы тенденций миграционных процессов. Проведен анализ миграционных процессов в Украине. Представлены результаты анализа динамики и современного состояния миграционных процессов. Оценено влияние внутренней миграции на экономику страны. На основе представленного анализа предложены направления совершенствования системы регулирования внутренней миграции. Расширено представление об основных принципах и направлениях государственной миграционной политики, которых должно придерживаться правительство Украины во время ее формирования. В статье проанализировано количество перемещенных лиц, нуждающихся в помощи за период 2016-2020 гг. на примере Управления социальной защиты населения Ясиноватской райгосадминистрации. Проведено исследование динамики выплаты ежемесячной адресной помощи в разрезе контингента получателей на территории Ясиноватского района Донецкой области, которые перемещаются с временно оккупированной территории и районов проведения антитеррористической операции за период 2016-2020 гг. Исследованы тенденции динамики основных показателей выполнения бюджетной программы 2501480 «Предоставление ежемесячной адресной помощи внутренне перемещенным лицам для покрытия расходов на проживание, в том числе на оплату жилищно-коммунальных услуг». Результаты этого исследования могут стать основой для формирования миграционной политики Украины по европейским стандартам. Признание и престиж Украине в мире зависят от четкости и обоснованности миграционной политики, от дальнейшего развития и эфффективности миграционных процессов.

Ключевые слова: миграционные процессы, рабочая сила, внутренне перемещенные граждане бюджетные программы, временное размещение, дискриминация, социальной защиты населения.

Migration processes have a great impact on the socio-economic development of the country, its territorial integrity and national security. The problem of population migration is a topical one for Ukraine. The article is devoted to the analysis of population migration processes and their impact on the country's economy. The content of the main mechanisms of regulating migration flows is analyzed. The analysis of the dynamics and the current state of the population migration process is presented. On the basis of the presented analysis the directions of improvement of the system of regulation of population migration are proposed. The reasons for the positive and negative effects of migration are examined. The opinions of experts on this problem are studied. The article contains forecasts of migration trends. An analysis of migration processes in Ukraine is conducted. The results of the analysis of the dynamics and current state of migration processes are presented. The impact of internal migration on the country's economy is assessed. On the basis of the analysis presented, directions for improving the system of internal migration regulation are proposed. The main principles and directions of the state migration policy to be followed by the government of Ukraine during its formation have been broadened. The article analyses the number of displaced persons in need of assistance for the period 2016-2020 by the example of the Social Protection Department of Yasynuvata Rayon State Administration. A study was conducted on the dynamics of monthly targeted assistance payment in the context of the contingent of recipients in Yasynuvata district of Donetsk region, who are displaced from the temporarily occupied territory and areas of the anti-terrorist operation for the period 2016-2020. Trends in key performance indicators of budget programme 2501480 "Monthly targeted assistance to internally displaced persons to cover living costs, including housing and utilities" were investigated. The results of this study may become the basis for the formation of Ukraine's migration policy according to European standards. The recognition and prestige of Ukraine depends on the clarity and soundness of its migration policy and on the further development and efficiency of its migration processes.

Keywords: migration processes, labour force, internally displaced citizens budget programmes, temporary accommodation, discrimination, social protection.

Постановка проблеми. Структура населення України фрормувалася під впливом історичних фрактів і соціально-економічних фракторів. Міграційні, етнічні та демограсрічні процеси неодноразово докорінно змінювали біосоціальну структуру українських просторів. Напрямок i інтенсивність цих процесів залежали від багатьох природних і соціальних фракторів. Міграційні переміщення визначалися зміною кліматичних умов, виснаженням або пошуком нових природних ресурсів, геополітичними змінами, економічними кризами, військовими консрліктами, дискримінаційною внутрішньою політикою тощо.
Масштаби міграції в Україні на теперішній час носять глобальний характер і ставлять завдання, успішне вирішення яких великою мірою впливають на соціально-економічний розвиток країни, рівень і якість життя населення, територіальну цілісність та національну безпеку. Тому дослідження впливу міграційних процесів населення на суспільство $€$ вельми актуально.

Аналіз останніх досліджень і публікацій Висвітлення важливих проблем із масової вимушеної міграції населення України було розкрито у дослідженнях українських науковців, табл. 1. 
Таблиця 1

Основні напрями дослідження проблем вимушеної міграції громадян України

\begin{tabular}{|c|c|}
\hline Автор & Основні напрями дослідження \\
\hline $\begin{array}{l}\text { О. Скрипник } \\
\text { [1] }\end{array}$ & $\begin{array}{l}\text { Розкрито сутність поняття «внутрішньо переміщені громадяни». } \\
\text { До внутрішньо переміщених громадян запропоновано віднести вимушених } \\
\text { переселенців, які залишили домівки, щоб зберегти власне життя та життя } \\
\text { близьких, для уникнення насилля та політично мотивованого переслідування } \\
\text { за свої переконання }\end{array}$ \\
\hline Е. Лібанова & $\begin{array}{l}\text { Обґрунтування необхідності ефективної державної політики підтримки } \\
\text { вимушених переселенців. Доведено, що одним із головних пріоритетів у } \\
\text { державній політиці є зміцнення співпраці всіх верств українського суспільства } \\
\text { для розбудови ефрективної системи підтримки вимушених переселенців, } \\
\text { що повинно ґрунтуватися на результатах наукових досліджень }\end{array}$ \\
\hline $\begin{array}{l}\text { І. Акімова } \\
\text { [3] }\end{array}$ & $\begin{array}{l}\text { Досліджено, що виникає необхідність створення державою механізму } \\
\text { фрінансування витрат на тимчасове розміщення вимушених переселенців }\end{array}$ \\
\hline $\begin{array}{l}\text { Т. Ягланд } \\
\text { [4] }\end{array}$ & $\begin{array}{l}\text { Визначено, що Україна вживає необхідні заходи для захисту найбільш } \\
\text { уразливих верств населення та їх прав }\end{array}$ \\
\hline
\end{tabular}

Вчені І. Гнибіденко, С. Гриневич, А. Кравченко, О. Заклекта, І. Рєліна зробили вагомий внесок у вирішення проблеми щодо обліку і регулювання міграційних процесів, але залишились невирішеними проблеми щодо обліку і регулювання процесів міграції населення на сході України.

Виділення невирішених раніше частин загальної проблеми. Державна політика України спрямована на реалізацію комплексних програм соціального захисту незахищених верств населення. 32014 р. до таких верств населення України належать громадяни, які були вимушені покинути своє постійне місце проживання на окупованій частині Донецької та Луганських областей, Автономної Республіки Крим і м. Севастополя, тобто населені пункти та території на яких органи державної влади тимчасово не здійснюють свої повноваження та населені пункти, що розташовані на лінії зіткнення. Майже півтора мільйона громадян України покинули свої домівки і виїхати на підконтрольну українській владі територію в пошуках захисту, а часто і просто порятунку. При цьому, внутрішньо переміщені громадяни (далі - ВПО) зіткнулися з численними проблемами, серед яких $€$ пошук місця тимчасового проживання, одержання кваліфрікованої медичної допомоги, оформлення, переоформлення документів, що засвідчують особу, підтвердження спеціального статусу осіб з інвалідністю або пенсійного забезпечення [5].

Отже, виникає необхідність визначення особливостей реалізації захисту та державної підтримки при виконанні бюджетної програми, яка діє у межах соціальної політики України щодо підтримки ВПО.
Формулювання цілей статті. Метою дослідження розробка пропозицій щодо покращення обліку і регулювання міграційних процесів на Сході України на основі проведення аналізу кількості облікованих осіб на території Донецької області Ясинуватського району та динаміки виплат щомісячної адресної допомоги в розрізі контингенту отримувачів.

Виклад основного матеріалу дослідження. Сучасний стан суспільного життя характеризується активізацією внутрішніх (внутрішньорегіональних і міжрегіональних) та міждержавних міграційних процесів.

Внутрішня міграція, не впливаючи на зміну чисельності населення країни, призводить до збільшення соціального напруги в суспільстві та підвищення рівня безробіття. Обсяги та спрямованість внутрішньодержавних міграцій зумовлюються значною мірою територіальними відмінностями у соціальноекономічному розвитку, різним рівнем життя населення, його структурою, політичними сракторами та ін.

Політичні події, що розпочалися в Україні в 2013 р., викликали необхідність регулювання міграційних процесів на державному рівні. Урядом України з метою соціальної підтримки та фрінансової допомоги внутрішньо переміщеним сім'ям (особам) у жовтні 2014 р. було прийнято Постанову Кабінету Міністрів України № 505 «Про надання щомісячної адресної допомоги внутрішньо переміщеним особам для покриття витрат на проживання, в тому числі на оплату житлово-комунальних послуг» [6]. На виконання діючої постанови зареєстровані, як внутрішньо переміщені особи пенсійного віку, особи з інвалідністю, діти 3 інвалідністю та інші особи, які пере- 
бувають у складних життєвих обставинах, мають право на отримання соціальних послуг за фрактичним місцем проживання чи перебування, основними серед яких є:

- щомісячна допомога на сплату житловокомунальних послуг для тимчасового проживання всіх членів родини;

- забезпечення соціальним та медичним пакетом послуг від благодійних організацій;

- відновлення соціальних виплат і пенсії за фрактичним місцем проживання, якщо громадянин має інший статус;

- продовження освіти, в тому числі за рахунок держави;

- отримання місця в дитячому садку і школі для дітей-переселенців;

- одержання матеріальної допомоги громадянам, які опинилися у складних життєвопобутових умовах.

Метою органів соціального захисту є реалізація державної політики на досягнення соціального захисту сімей, що опинились в складних життєвих обставинах, зокрема через низькі доходи. Звернувшись, громадяни отримують своєчасну та професійну допомогу, включаючи фрінансову, яка спрямовується на швидкий вихід із кризи та подолання тимчасових, складних, життєвих обставин.

Проаналізовано на прикладі Управління соціального захисту населення Ясинуватської райдержадміністрації кількість переміщених осіб за період 2016-2020 рр., які потребують допомоги, табл. 2.

Спостерігаємо, що починаючи з 2016 р. на території Ясинуватського району відбулася масова міграція населення з тимчасово окупованої території. У період 2016-2020 рр. відстежується облікована чисельність більш ніж 7 тисяч осіб, з них вагома частина це працездатне населення та неповнолітні діти.

Згідно діючого законодавства органи соціального захисту виконують фрункцію з одержання державного фрінансування на потреби переміщених осіб та членів їх сімей з обов'язковим звітування про виконання, витрачання обсягів державних асигнувань у звітності державних органів казначейської служби України.

Фактичні дані щодо кількісті осіб, що звернулись за допомогою, по управлінню в розрізі категорій отримувачів наведено у табл. 3.

Таблиця 2

Динаміка кількості облікованих осіб на території Донецької області Ясинуватського району, які переміщуються 3 тимчасово окупованої території та районів проведення антитерористичної операції за період 2016-2020 рр. в розрізі категорій отримувачів

\begin{tabular}{|c|c|c|c|c|c|c|c|}
\hline Рік & \multirow{2}{*}{$\begin{array}{c}\text { Обліковано } \\
\text { осіб }\end{array}$} & $\begin{array}{c}\text { Обліковано } \\
\text { сімей }\end{array}$ & $\begin{array}{c}\text { Працездат- } \\
\text { них осіб }\end{array}$ & Дітей & $\begin{array}{c}\text { Осіб } \\
\text { з інвалід- } \\
\text { ністю }\end{array}$ & $\begin{array}{c}\text { Пенсіо- } \\
\text { нерів }\end{array}$ & $\begin{array}{c}\text { Темп росту } \\
\text { осіб, \% } \\
\text { 2016 р. }\end{array}$ \\
\hline 2016 & 7350 & 6451 & 3195 & 2966 & 176 & 1013 & \\
\hline 2017 & 7669 & 6692 & 3295 & 2935 & 193 & 1246 & $4 \%$ \\
\hline 2018 & 7312 & 6128 & 3201 & 2937 & 199 & 975 & $-0,5 \%$ \\
\hline 2019 & 7313 & 6127 & 3198 & 2773 & 199 & 1143 & $-0,5 \%$ \\
\hline 2020 & 7311 & 6128 & 3185 & 2688 & 198 & 1458 & $-0,5 \%$ \\
\hline
\end{tabular}

Джерело: складено на основі статистичних даних УСЗН Ясинуватської РДА

Таблиця 3

Динаміка виплати щомісячної адресної допомоги на території Донецької області Ясинуватського району, які переміщуються 3 тимчасово окупованої території та районів проведення антитерористичної операції за період 2016-2020 рр.

\begin{tabular}{|c|c|c|c|c|c|c|c|}
\hline \multirow{2}{*}{ Рік } & \multirow{2}{*}{$\begin{array}{c}\text { Отримують } \\
\text { допомогу } \\
\text { осіб }\end{array}$} & $\begin{array}{c}\text { Отримують } \\
\text { допомогу } \\
\text { сімей }\end{array}$ & $\begin{array}{c}\text { Працездат- } \\
\text { них осіб }\end{array}$ & дітей & $\begin{array}{c}\text { Осіб } \\
\text { з інвалід- } \\
\text { ністю }\end{array}$ & $\begin{array}{c}\text { Пенсіоне- } \\
\text { рів }\end{array}$ & $\begin{array}{c}\text { Темп росту } \\
\text { осіб, \% } \\
\text { відосно } \\
\text { 2016 р. }\end{array}$ \\
\hline 2016 & 1144 & 1108 & 514 & 365 & 35 & 230 & \\
\hline 2017 & 1306 & 1206 & 655 & 404 & 35 & 212 & $14 \%$ \\
\hline 2018 & 1483 & 1318 & 693 & 574 & 26 & 190 & $29 \%$ \\
\hline 2019 & 1170 & 903 & 551 & 401 & 27 & 191 & $0,2 \%$ \\
\hline 2020 & 1045 & 878 & 489 & 378 & 27 & 231 & $-8 \%$ \\
\hline
\end{tabular}

Джерело: складено на основі статистичних даних УСзН Ясинуватської РДА 
3 наведеної інфрормації можливо зробити висновок, що кількість громадян які потребують фрінансової підтримки від держави майже у 4,5-5 разів $є$ меншою від кількості тих, хто звернувся, за встановленням статусу «Внутрішньо переміщена особа», що $€$ позитивним моментом та свідчить про те, що більшість вимушених переселенців $€$ заможні громадяни та не потребують допомоги з боку держави.

Тобто, громадяни мають у володінні житлові приміщення на підконтрольній території України або $є$ власниками депозитних рахунків у загальних розмірах більших ніж закріплено на законодавчому рівні.

Також, спостерігається тенденція зменшення кількості потребуючих щомісячної грошової допомоги на проживання про це свідчить від'ємний показник «Темпу росту», отже вимушені громадяни поступово налагодили свій побут та не потребують фрінансової підтримки та турботи з боку держави.

Практичний досвід УСЗН Ясинуватської РДА свідчить про ефективне фрункціонування програм соціальної політики, які направлені на задоволення соціальних, матеріальних, побутових та психологічних послуг ВПО. Досліджено, що УСЗН Ясинуватської РДА виконує фрункцію 3 одержання державного фрінансування на потреби ВПО та членів їх сімей 3 обов'язковим звітування про виконання, витрачання обсягів державних асигнувань у звітності державних органів казначейської служби України.

На виконання Постанови Кабінету Міністрів України № 505 «Про надання щомісячної адресної допомоги внутрішньо переміщеним особам для покриття витрат на проживання, в тому числі на оплату житлово-комунальних послуг» затверджується початкові кошторисні призначення за бюджетною програмою 2501480 «Надання щомісячної адресної допомоги внутрішньо переміщеним особам для покриття витрат на проживання, в тому числі на оплату житлово-комунальних послуг» [6].

Досліджено тенденції динаміки основних показників виконання цієї бюджетної програми на основі даних УСЗН Ясинуватської РДА протягом 2016-2020 рр. Так, при плануванні розрахунків видатків за бюджетною програмою з 2016 р. спостерігається тенденція до збільшення фрінансування з бюджету держави для охоплення всіх потребуючих верств населення.

Встановлено, що за напрямами фрінансової соціальної підтримки ВПО залучено великий обсяг надходжень з бюджету дер- жави для коригування додаткової потреби в наданні матеріальної допомоги протягом 2016-2020рр., що підтверджує збільшення чисельності постраждалих від збройного конорлікту на сході України [7]. При цьому, спостерігається тенденція збільшення обсягів фрактичного виконання Бюджетної програми, яка підтверджується перевиконанням на 1,45\% фрактичних видатків на фрінансування матеріальної допомоги ВПО у 2020 р. порівняно з показниками 2016 р., що підтверджує, що протягом збройного конфрлікту на сході України переміщені громадяни не облаштували свого повноцінного побуту.

Таким чином, можна стверджувати, що громадяни з числа ВПО за різними обставинами одержали допомогу з бюджету країни, надавши неправдиву, неповну, неправомірну і неякісну інфоормацію про свій фрінансовий, матеріальний стан, житлові приміщення, депозити на рахунках банківських установ, автомобілі, кількість зареєстрованих за адресою громадян, тощо. За таких обставин, 3 одного боку ми спостерігаємо, про всіляку підтримку державою незахищених верств населення $з$ числа переміщених громадян України, а з іншого боку - про наявність серед ВПО таких громадян, що неправомірно отримують адресну допомогу. При цьому, отримавши надмірну грошову допомогу такі громадяни не поспішають її повертати, навіть при виявленні фракту порушення законодавства України.

Працівники соціальних установ ведуть постійну інформаційно-роз'яснювальну роботу 3 такими громадянами для здійснення погашення, утримання грошових призначень для повернення фрінансування до бюджету держави в найкоротші терміни. Установи соціального захисту збільшують свої видатки та освоюють нові напрямки діяльності, але важливим залишається питання щодо цільового використання коштів.

Висновки. Переселення громадян відбувається з різних причин, але головною $€$ проведення воєнних дій, які неможливо контролювати. Щоб зупинити міграцію населення на Сході країни, потрібно створити комсрортні умови для проживання людей. Необхідно розробити якісний план покращення політики та ресрорм в нашій країні, i, як наслідок, проблема вимушеної міграції буде припинено.

Внутрішня міграція, не впливаючи на зміну чисельності населення країни, призводить до збільшення соціального напруги в суспільстві та підвищення рівня безробіття. Встановлено, що проблема обліку і регулювання міграцій- 
них процесів є надзвичайно важливою і вирішувати її потрібно якнайшвидше. Необхідно і далі надавати державою підтримку незахищених верств населення 3 числа переміщених громадян України. Працівники соціальних установ повинні постійно вести інфрормаційнороз'яснювальну роботу серед громадян. Результати цього дослідження можуть стати основою для формування міграційної політики України за європейськими стандартами.

\section{СПИСОК ВИКОРИСТАНИХ ДЖЕРЕЛ:}

1. Історія європейської інтеграції : навчальний посібник / О.М. Скрипник. Умань : ВПЦ «Візаві», 2019. 370 с.

2.Либанова Е.М. Вимушене переселення 3 Донбасу: масштаби та виклики для України. URL: http://dspace.nbuv.gov.ua/bitstream/handle/123456789/73424/04-Libanova.pdf?sequence=1 (дата звернення: 10.04.2021).

3.Акімова І. Стрес-тест-2017: (не)прохідність для економіки України. URL: https://zn.ua/ukr/macrolevel/ stres-test-2017-ne-prohidnist-dlya-ekonomiki-ukrayini-ninishniy-rik-zhorstko-protestuye-vladu-na-yiyi-zdatniststvoriti-realniy-maydanchik-dlya-zrostannya-nacionalnoyi-ekonomiki-_.html (дата звернення: 10.04.2021).

4. Генсек Совета Европы рассказал о рисках для демократии и прав человека в Украине. URL: https://www.eurointegration.com.ua/rus/news/2016/04/27/7048508/ (дата звернення: 10.04.2021).

5.Беззуб І. Урегулювання правового становища внутрішньо переміщених осіб на території України. Центр досліджень соціальних комунікацій НБУВ. URL: http://nbuviap.gov.ua/index (дата звернення: 01.03.2021).

6. Постанова Кабінету Міністрів України № 505 від 01 жовтня 2014 року «Про внутрішньо переміщених осіб». Дата оновлення: 24.08.2019. URL: https://zakon.rada.gov.ua/laws/show/505-2014-\%D0\%BF

7.Подлужна Н.О., Гук Г.В. Особливості реалізації бюджетної програми підтримки внутрішньо переміщених громадян в Україні. Збірник тез доповідей учасників XVIII Всеукраїнської наукової консеренції «Розвиток системи обліку, аналізу та аудиту в Україні: теорія, методологія, організація». Київ : ДП «Інфрорм.-аналіт. агентство», 2020. С. 252-255.

\section{REFERENCES:}

1. Istoriya yevropejskoyi integracziyi: navchalnij posibnik (2019) / O.M. Skripnik. Uman: VPCz «Vizavi», 370 p.

2. Vimushene pereselennya z Donbasu: masshtabi ta vikliki dlya Ukrayini. URL: http://dspace.nbuv.gov.ua/ bitstream/handle/123456789/73424/04-Libanova.pdf?sequence=1

3. Stres-test-2017: (ne)prokhidni`st dlya ekonomiki Ukrayini. URL: https://zn.ua/ukr/macrolevel/stres-test-2017ne-prohidnist-dlya-ekonomiki-ukrayini-ninishniy-rik-zhorstko-protestuye-vladu-na-yiyi-zdatnist-stvoriti-realniy-maydanchik-dlya-zrostannya-nacionalnoyi-ekonomiki-_.html

4. Gensek Soveta Evropy rasskazal o riskakh dlya demokratii i prav cheloveka $v$ Ukraine. URL: https://www.eurointegration.com.ua/rus/news/2016/04/27/7048508/

5. Bezzub I. Uregulyuvannya pravovogo stanovishha vnutrishn`o peremi’shhenikh osib na teritoriyi Ukrayini. Czentr doslidzhen soczialnikh komunikaczij NBUV. URL: http://nbuviap.gov.ua/index

6. Postanova Kabinetu Ministriv Ukrayini № 505 vid 01 zhovtnya 2014 roku «Pro vnutrishno peremi`shhenikh osib». Data onovlennya: 24.08.2019. URL: https://zakon.rada.gov.ua/laws/show/505-2014-\%D0\%BF

7. Podluzhna N.O., Huk H.V. (2020) Osoblyvosti realizatsii biudzhetnoi prohramy pidtrymky vnutrishno peremishchenykh hromadian $v$ Ukraini. Zbirnyk tez dopovidei uchasnykiv XVIII Vseukrainskoi naukovoi konferentsii «Rozvytok systemy obliku, analizu ta audytu v Ukraini: teoriia, metodolohiia, orhanizatsiia». Kyiv: DP «Inform.-analit. ahentstvo». 